\title{
Physiological role of the GInK signal transduction protein of Escherichia coli: survival of nitrogen starvation
}

Timothy A. Blauwkamp and Alexander J. Ninfa* Department of Biological Chemistry, University of Michigan Medical School, 1301 E. Catherine, Ann Arbor, MI 48109-0606, USA.

\section{Summary}

Escherichia coli contains two PII-like signal transduction proteins, PII and GInK, involved in nitrogen assimilation. We examined the roles of PII and GInK in controlling expression of $g I n A L G, g / n K$ and nac during the transition from growth on ammonia to nitrogen starvation and vice versa. The PII protein exclusively controlled gInALG expression in cells adapted to growth on ammonia, but was unable to limit nac and $g / n K$ expression under conditions of nitrogen starvation. Conversely, GInK was unable to limit gInALG expression in cells adapted to growth on ammonia, but was required to limit expression of the gInK and nac promoters during nitrogen starvation. In the absence of GInK, very high expression of the gInK and nac promoters occurred in nitrogen-starved cells, and the cells did not reduce gInK and nac expression when given ammonia. Thus, one specific role of GInK is to regulate the expression of Ntr genes during nitrogen starvation. GInK also had a dramatic effect on the ability of cells to survive nitrogen starvation and resume rapid growth when fed ammonia. After being nitrogen starved for as little as $10 \mathrm{~h}$, cells lacking GInK were unable to resume rapid growth when given ammonia. In contrast, wild-type cells that were starved immediately resumed rapid growth when fed ammonia. Cells lacking GInK also showed faster loss of viability during extended nitrogen starvation relative to wild-type cells. This complex phenotype resulted partly from the requirement for GInK to regulate nac expression; deletion of nac restored wild-type growth rates after ammonia starvation and refeeding to cells lacking GInK, but did not improve viability during nitrogen starvation. The specific roles

Accepted 11 July, 2002. *For correspondence. E-mail aninfa@ umich.edu; Tel. (+1) 734763 8065; Fax (+1) 7347634581. of GInK during nitrogen starvation were not the result of a distinct function of the protein, as expression of PII from the gInK promoter in cells lacking GInK restored the wild-type phenotypes.

\section{Introduction}

Previous studies have suggested that $\sigma^{54}$-dependent $\mathrm{Ntr}$ genes of Escherichia coli form a gene cascade controlling a sequence of responses to nitrogen limitation (Fig. 1). The initial response to nitrogen limitation is activation of glutamine synthetase activity and expression of its structural gene, $g \ln A$, along with the adjacent $g \ln L(n t r B)$ and $g \ln G(n t r C)$ genes. gInL and $g / n G$ encode the twocomponent signal transduction system responsible for expression from Ntr promoters. The $\mathrm{g} / \mathrm{hL}$ product, NRII, is a kinase and phosphatase controlling the phosphorylation state of the gInG product, NRI (Fig. 1). NRI P activates transcription from nitrogen-regulated $\sigma^{54}$-dependent promoters by binding to enhancers located near the promoters (reviewed by Kustu et al., 1989; Merrick and Edwards, 1995; Ninfa et al., 2000).

PII and the related GInK protein control the phosphorylation state of NRI by stimulating the phosphatase activity of NRII (Fig. 1). The ability of GInK and PII to regulate the activities of NRII is in turn regulated by intracellular signals of carbon and nitrogen availability via allosteric control and covalent modification of these proteins (reviewed by Ninfa et al., 2000). As the $g / n L$ and $g / n G$ products are both regulators of $g \operatorname{InALG}$ transcription and encoded by $g$ InALG, under nitrogen-limiting conditions, a positive autoregulatory loop results (Fig. 1). Immunoblotting studies have indicated that the intracellular concentration of NRI and NRII is increased upon nitrogen limitation (Reitzer and Magasanik, 1985; Atkinson and Ninfa, 1993; M. R. Atkinson et al., 2002a). This increased intracellular concentration of $\mathrm{NRI}$, presumably in the form of $\mathrm{NRI} \sim \mathrm{P}$, is required for the expression of other nitrogenregulated genes under conditions of nitrogen limitation (Pahel et al., 1982). The glnK and nac promoters are two such promoters. Analysis of the DNA sequence adjacent to these promoters indicates that they contain weaker enhancer elements than does the gInALG control region, 


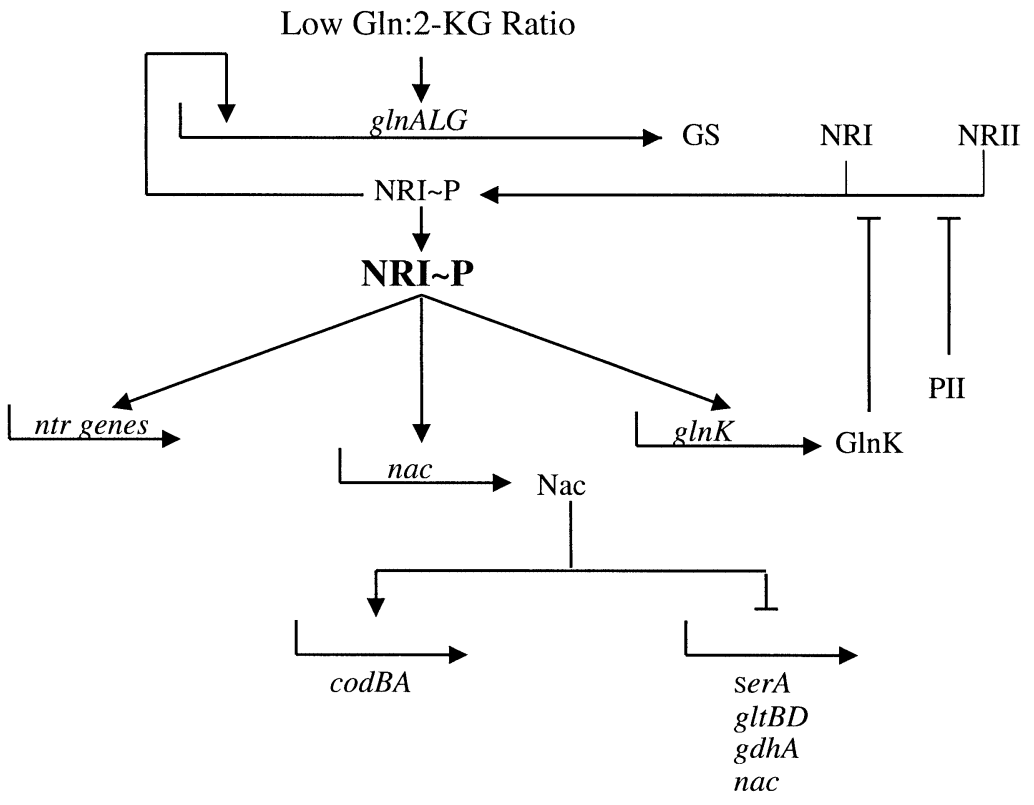

Fig. 1. Summary of Ntr gene cascade. Nitrogen limitation in $E$. coli activates transcription of the $g \ln A L G$ operon, encoding glutamine synthetase and the two-component system responsible for induction of genes lower in the Ntr gene cascade. Some genes in this second tier, such as $\mathrm{glnH}$ and the aut operon, are responsible for assimilating nitrogen from sources other than ammonia, whereas others, such as GlnK and Nac, regulate cellular physiology on a wider scale by affecting the transcription of several genes.

and in vitro transcription with purified components has indicated that transcription from the nac and gInK promoters requires a higher concentration of NRI P than does transcription from the nitrogen-regulated $g \ln A$ promoter (Feng et al., 1995; M. R. Atkinson et al., 2002a). In the case of the nac promoter, it was shown that replacement of the weak nac enhancer by the potent $g \ln A$ enhancer resulted in increased sensitivity to activation by NRI P (Feng et al., 1995). Experiments with intact cells showed that the $g I n A$ promoter was activated earlier than the glnK and nac promoters as cells exhaust a limiting ammonia supply and become nitrogen starved (M. R. Atkinson et al., 2002a). Thus, it appears that the intrinsic properties of the various Ntr promoters result in their activation and inactivation in a defined sequence as the intracellular concentration of NRI P rises and falls.

The amplification of the positive autoregulatory loop is held in check by PII and GInK via NRII (Fig. 1). The absence of PII causes amplification of $\mathrm{NRI} P$ levels to proceed until $g \ln A L G$ is fully expressed and $g \operatorname{lnK}$ is expressed at a low level (Bueno et al., 1985; M. R. Atkinson et al., 2002a). Alternatively, in the absence of GInK, gInALG expression was regulated normally and no obvious phenotype could be attributed the cells lacking GInK (Atkinson and Ninfa, 1998). However, cells lacking both PII and GlnK ( $g \ln B$ glnK) display an obvious growth defect when grown on defined minimal medium resulting from unregulated activity of NRII (Atkinson and Ninfa, 1998). We showed recently that this growth defect resulted from the expression of the nac gene, as the triple mutant $g \ln B$ glnK nac strain was able to grow at wild-type rates on defined medium (Blauwkamp and Ninfa, 2002).
The position of $g \ln B$ and $g \ln K$ in the regulatory cascade (PII being constitutive and GInK inducible) appears to be a major determinant of their ability to regulate expression of $\operatorname{gln} A L G$ (M. R. Atkinson et al., 2002b). When cells contained PII expressed from the glnK promoter as their sole PII-like protein, PII was unable to regulate the expression of $g I n A L G$. That is, PII expressed from the $g I n K$ promoter behaved the same as GInK expressed from the glnK promoter with regard to $g I n A L G$ regulation. Alternatively, GInK acquired the ability to regulate $\operatorname{gln} A L G$ when its expression was rendered constitutive or when it was expressed earlier in the gene cascade (M. R. Atkinson et al., 2002b). Expression of either PII or GInK from the glnK promoter as the sole PII-like protein in $g \ln B \mathrm{~g} / \mathrm{lnK}$ minus cells was sufficient to prevent the growth defect now known to be caused by nac expression (Blauwkamp and Ninfa, 2002). Thus, we may surmise that either PII or GInK, when expressed from the glnK promoter, is able to regulate nac expression by acting through NRII. These results led to the conclusion that the unique regulatory roles of PII and GInK were mainly the result of their promoters and the consequent timing and levels of their expression (M. R. Atkinson et al., 2002b; Blauwkamp and Ninfa, 2002).

Studies with gene fusions have indicated that, in wildtype cells grown with a limiting concentration of ammonia, the $g \ln A$ promoter is partially activated as the ammonia is being consumed, and this promoter and the gInK and nac promoters are sharply activated when the ammonia is used up and starvation ensues (M. R. Atkinson et al., 2002b). Here, we used lacZYA fusions to study the regulation of the $g \ln A, g \ln K$ and nac promoters in cells lacking either PII or GInK. Our results indicate that PII functions 
primarily during nitrogen-rich growth to control gInALG expression, whereas GInK prevents unchecked expression of Ntr genes upon nitrogen starvation. These observations suggested that mutation of $g / n K$, in an otherwise wild-type background, should result in a physiological state similar to that of the $g \ln B$ glnK double mutant upon nitrogen starvation. We tested this prediction and observed that the glnK mutant had a severe defect in the growth rate recovery from nitrogen starvation that was largely due to runaway expression of nac.

\section{Results}

Use of gene fusions to study the distinct roles of PII and GInK in the regulation of the glnA, glnK and nac promoters

Previous studies described the construction of fusions of the $g \ln A, g \ln K$ and nac promoters to promoterless lacZYA structural genes and the recombination of these fusions into a transcriptionally isolated 'landing pad' within the trp operon of Escherichia coli that had been designed for this purpose (Simons et al., 1987; Atkinson and Ninfa, 1998; M. R. Atkinson et al., 2002a). We examined the expression of these three transcriptional fusions in wildtype cells, cells lacking PII ( $g$ lnB mutants, strain B) and cells lacking GInK (glnK mutants, strain K). In our experimental protocol, cells were grown on a low concentration of ammonia as the sole nitrogen source and became nitrogen starved as the ammonia was exhausted. After the ammonia had been exhausted and the cells had been maintained in the starved state for $>18 \mathrm{~h}$, the cultures were fed a high concentration of ammonia $[0.2 \%(\mathrm{w} / \mathrm{v})$ final concentration], and the effect of this addition on cell growth and fusion expression was monitored.

In the wild-type background, cells growing on excess glucose and $0.005 \%(\mathrm{w} / \mathrm{v})$ ammonium sulphate had a basal level of $g \ln A p-l a c Z Y A$ expression, which gradually increased during exponential growth as the cells were using up the limiting concentration of ammonia (Fig. 2A, white bars). Expression of this fusion reached its maximum level just after the ammonia became exhausted and cell growth ceased. Thereafter, the level of $\beta$-galactosidase from the $g \ln A p-l a c Z Y A$ expression was maintained at between $50 \%$ and $70 \%$ of the maximum level while the cells were starved, and was decreased upon addition of ammonia as the cells resumed growth (Fig. $2 \mathrm{~A}$ ). In the experiment shown, which was typical, a 12-fold dynamic range of $\beta$-galactosidase from the gInAp-lacZYA fusion was obtained as cells growing on ammonia became starved. This is consistent with previous results, which showed a similar dynamic range of gInAp-lacZYA expression upon ammonia exhaustion (M. R. Atkinson et al., 2002a).
Previous studies showed that, in the wild-type background, expression of the gInKp-lacZYA fusion in ammonia run-out experiments only occurred when the ammonia became exhausted and cell growth stopped (M. R. Atkinson et al., 2002a). Our results are in agreement with this observation. We also show that the level of $\beta$ galactosidase from the glnKp-lacZYA fusion remained high throughout the period of starvation and decreased rapidly when starved cells were fed ammonia (Fig. 2B, white bars).

Previous studies showed that the nacp-lacZYA fusion expression pattern in the wild-type background was similar to the glnKp-lacZYA fusion in that it was only expressed as the cells ran out of ammonia and ceased growing (M. R. Atkinson et al., 2002a). Our experiments are consistent with those results and show that the level of $\beta$-galactosidase from the nacp-lacZYA fusion remained high throughout the period of starvation and decreased rapidly when the cells were fed ammonia and resumed growth (Fig. 2C, white bars).

The three fusions were next studied in cells lacking PII (strain B). In this background, the dynamic range of $\beta$-galactosidase from the gInAp-lacZYA fusion was reduced to twofold as a result of an approximately sixfold elevation in the level of fusion expression during exponential growth on ammonia (Fig. 2A, solid bars). The level of $\beta$-galactosidase from the $g \ln A p-l a c Z Y A$ fusion was again maintained at between $50 \%$ and $80 \%$ of its maximum level throughout the starvation phase and decreased when the cells were fed ammonia and resumed growth. Basal expression of the gInKp-lacZYA and nacp-lacZYA fusions during growth on ammonia was elevated to about $25 \%$ of the respective nitrogen-starved levels of wild-type cells (Fig. 2B and C, solid bars respectively). With both these fusions, the level of $\beta$-galactosidase was increased further as the cells exhausted the ammonia and ceased growth, remained relatively constant throughout the starvation phase and was decreased when the cells were fed ammonia and resumed growing. To summarize, in the absence of PII, the level of expression from the three promoters ( $g \ln A p, g / n K p$, nacp) was elevated during exponential growth on ammonia, but similar to that observed in the wild-type background after the ammonia had been exhausted and growth stopped (compare white bars with solid bars in Fig. 2). As in the wild-type background, the expression of all three promoters decreased when ammonia was added to starved cells (Fig. 2).

The three fusions were next studied in cells lacking GInK (strain K). We used a non-polar null mutation in glnK for our studies, so that the cells are genotypically $g l n K^{-}$ $\mathrm{amtB}^{+}$(Table 1). This allele of $\mathrm{glnK}$, derived from strain $\mathrm{WCH} 30$, was introduced into the wild-type background used in our studies. Cells lacking GInK were observed to have a dramatic defect in the recovery from starvation. 
A

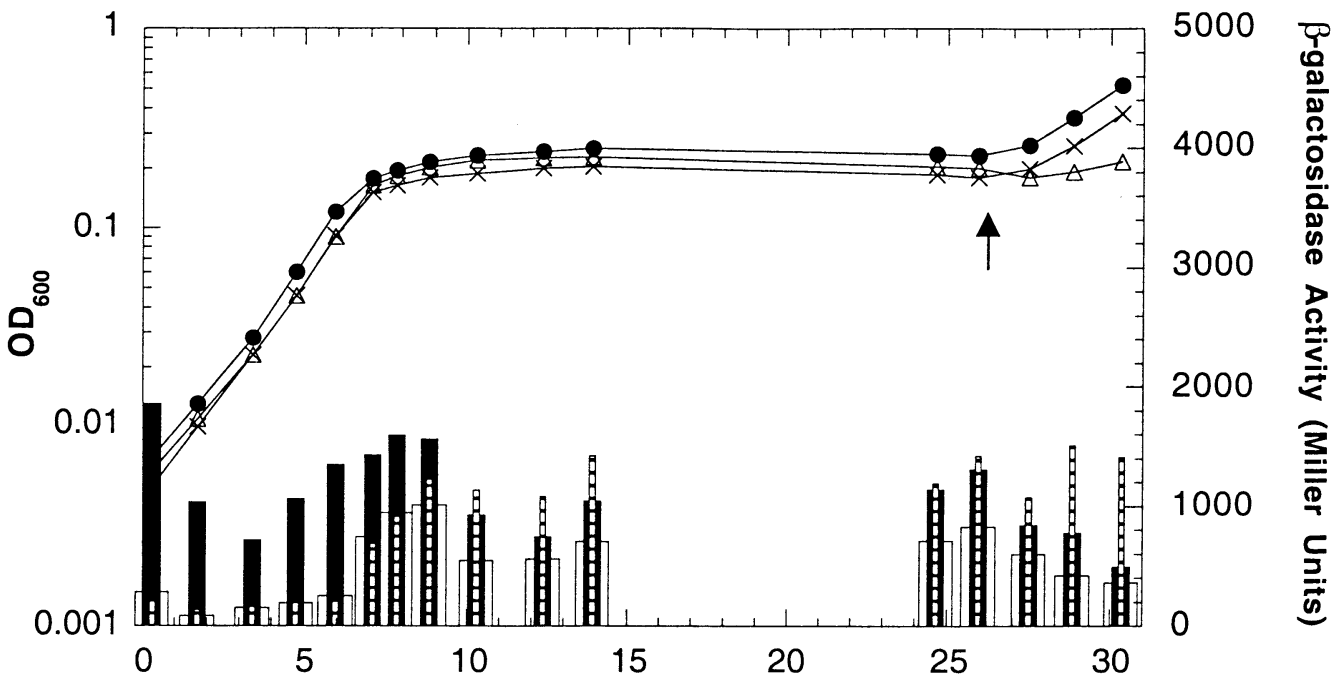

B

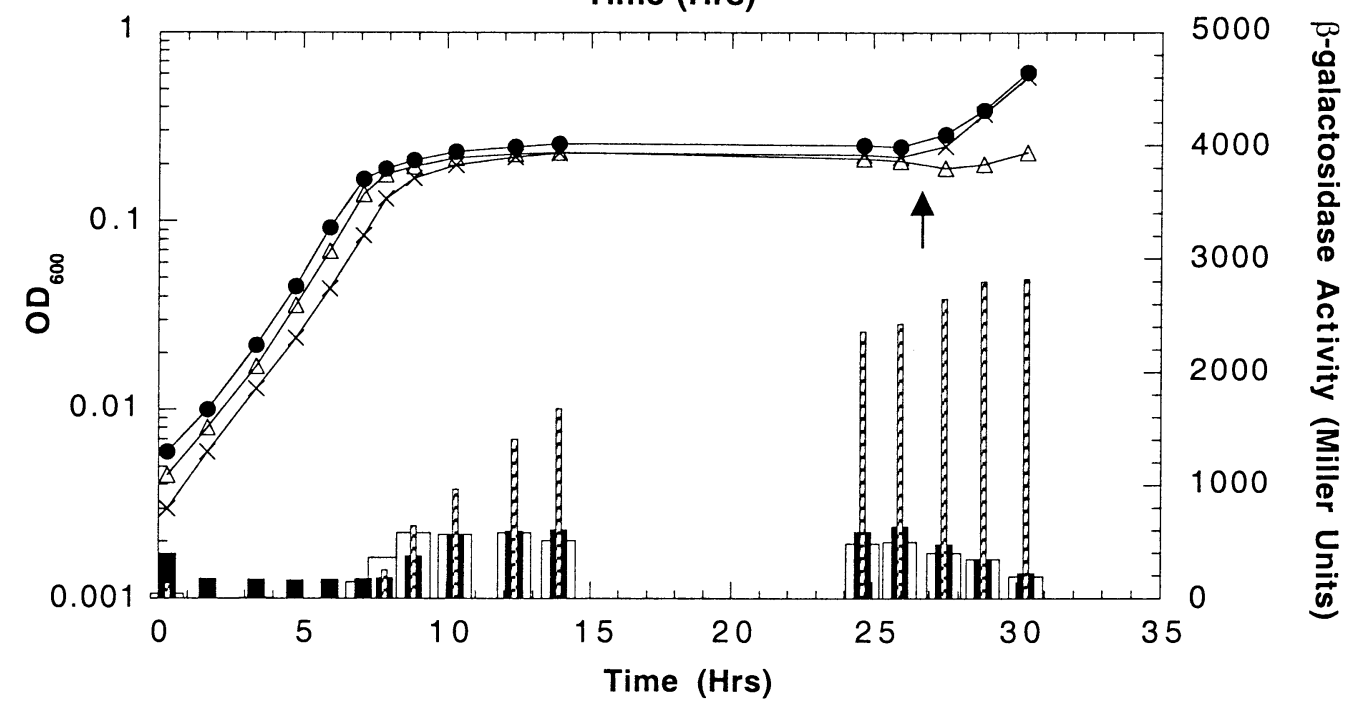

C

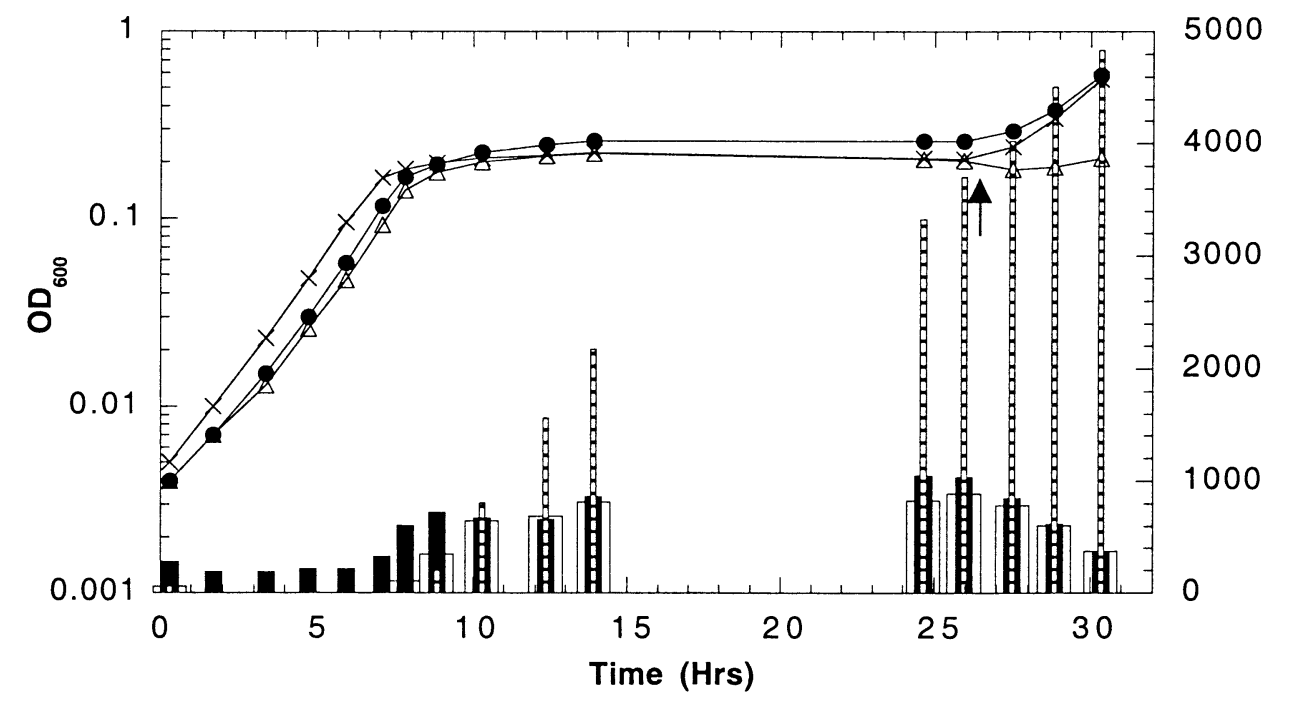

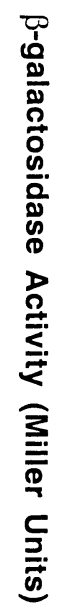


Table 1. Strains and plasmids used in this study.

\begin{tabular}{|c|c|c|}
\hline Strain ${ }^{a}$ & Relevant genotype ${ }^{b}$ & Source or construction \\
\hline WT (YMC10) & endA1 thi-1 hsdR17 supE44 $\Delta / a c U 169$ hutC $_{\text {klebs }}$ & Backman et al. (1981) \\
\hline B (RB9060) & $\Delta g \ln B$ & Bueno et al. (1985) \\
\hline $\mathrm{WCH} 30$ & $\Delta$ lacU169 endA1 thi-1 hsdR17 supE44 hutC ${ }_{K} \Omega G^{r} \ldots \Delta g \operatorname{lnK} 1$ & Arcondeguy et al. (1999) \\
\hline $\mathrm{K}(\mathrm{K} 3)$ & $\Omega \mathrm{Gm}^{\mathrm{r}} \ldots \Delta g \ln K 1$ & Blauwkamp and Ninfa (2002) \\
\hline$N(\mathrm{~N} 2)$ & nac::chl ${ }^{r}$ & Blauwkamp and Ninfa (2002) \\
\hline $\mathrm{KN}$ & $\Omega \mathrm{Gm}^{\mathrm{r}} \ldots \Delta g \ln K 1$ nac::chl' & $\mathrm{K} 3 \times \mathrm{N} 2 \mathrm{P} 1$ vir \\
\hline $\mathrm{K}[\mathrm{g} \operatorname{lnKp}-\mathrm{B}]$ & 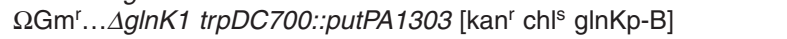 & $\mathrm{K}_{3} \times \mathrm{MAKpB2} \mathrm{P} 1$ vir \\
\hline $\mathrm{K}[\mathrm{g} \ln \mathrm{Bp}-\mathrm{B}]$ & 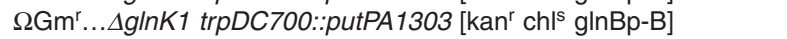 & $\mathrm{K}_{3} \times$ MABtrp8 P1 vir \\
\hline $\begin{array}{l}\text { YMC10[glnKp-lacZYA] } \\
(\text { YMC10 } \phi)\end{array}$ & 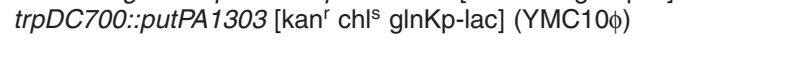 & Atkinson and Ninfa (1998) \\
\hline$B[g \operatorname{lnKp}-l a c Z Y A](B \phi)$ & 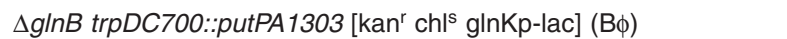 & Atkinson and Ninfa (1998) \\
\hline K[glnKp-lacZYA] & 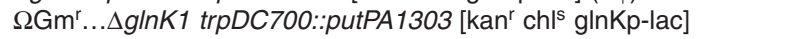 & $\mathrm{K}_{3} \times \mathrm{TE} \phi \mathrm{P} 1$ vir \\
\hline $\begin{array}{l}\text { YMC10[glnAp-lacZYA] } \\
\text { (YMC10Apф2) }\end{array}$ & trpDC700::putPA1303[kan' $\left.{ }^{r} l^{s} \mathrm{glnAp2}-\mathrm{lac}\right](Y M C 10 A p \phi 2)$ & M. R. Atkinson et al. (submitted) \\
\hline$B[g \ln A p-l a c Z Y A]$ & $\Delta g \ln B$ trpDC700::putPA1303[kanchls glnAp2-lac] (BApф2) & B $\times$ MAAplac3 P1 vir \\
\hline$K[g \ln A p-l a c Z Y A]$ & $\Omega \mathrm{Gm}^{\mathrm{r}} \ldots \Delta \mathrm{g} \ln K 1$ trpDC700::putPA1303 $\left[\mathrm{kan}^{\mathrm{r}} \mathrm{chl}^{\mathrm{s}} \mathrm{glnAp2-lac}\right]$ & $\mathrm{K}_{3} \times$ MAAplac3 P1 vir \\
\hline WT [nacp-lacZYA] & 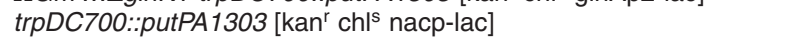 & Blauwkamp and Ninfa (2002) \\
\hline$B[$ nacp-lacZYA] & $\Delta g \ln B$ trpDC700::putPA1303[kan'chlsnacp-lac] & RB9060 × YMC10[nacp-lacZYA] P1 vir \\
\hline$K[$ nacp-lacZYA] & 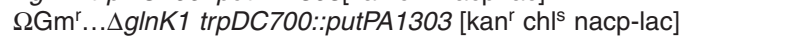 & $\mathrm{K} 3 \times \mathrm{YMC10}$ [nacp-lacZYA] P1 vir \\
\hline MAAplac3 & recD1903::Tn10 trpDC700::putPA1303[kan'chls glnAp2-lac] & M. R. Atkinson et al. (submitted) \\
\hline TE $\phi$ & recD1903::Tn 10 trpDC700::putPA1303 [kan ${ }^{r} \mathrm{chl}^{\mathrm{s}}$ glnKp-lac] (TE $\left.\phi\right)$ & Atkinson and Ninfa (1998) \\
\hline TE-Np $\phi$ & recD1903::Tn 10 trpDC700::putPA1303 [kan ${ }^{r} \mathrm{chl}^{\mathrm{s}}$ nacp-lac] & Blauwkamp and Ninfa (2002) \\
\hline MAKpB2 & recD1903::Tn10 trpDC700::putPA1303 [kan $\left.{ }^{\mathrm{r}} \mathrm{chl}^{\mathrm{s}} \mathrm{glnKpB}\right]$ & M. R. Atkinson et al. (submitted) \\
\hline MABtrp8 & recD1903::Tn 10 trpDC700::putPA1303 [kan $\left.{ }^{r} \mathrm{chl}^{\mathrm{s}} \mathrm{glnBpB}\right]$ & M. R. Atkinson et al. (submitted) \\
\hline
\end{tabular}

a. Parenthesis bracket strain names as designated in the reference given.

b. All strains were derived from YMC10, except WCH30, TE $\phi$ and TENp $\phi$.

That is, once they had become starved by exhaustion of the limiting ammonia and held in the starved state for about $19 \mathrm{~h}$, they were unable to resume growth rapidly upon being fed either high or low concentrations of ammonia [Fig. 2, triangles shows the results of refeeding with a high ammonia concentration of $0.2 \%(\mathrm{w} / \mathrm{v})$ ]. Indeed, a period of decreasing culture turbidity was observed upon addition of ammonia to starved strain $\mathrm{K}$. The regulation of gInAp-lacZYA expression in this strain appeared to be essentially normal, except that expression of the fusion was not reduced upon addition of ammonia to starved cells (Fig. 2A, hatched bars). As expected, nacp-lacZYA and $g$ InKp-lacZYA fusion expression was similar to wild type during exponential growth on ammonia, in that they were not expressed (Fig. 2B and C, hatched bars). However, as the cells became starved by exhaustion of ammonia, expression of these two promoters increased in a 'runaway' fashion, increasing at approximately the same rate as wild-type cells, but reaching a level approximately fivefold higher than that encountered in starved wild-type cells (Fig. 2B and $\mathrm{C}$, hatched bars). This very high expression of the glnKp-lacZYA and nacp-lacZYA fusions was not reduced upon addition of ammonia to starved cells; rather, expression from these fusions continued to increase even after the addition of ammonia (Fig. 2B and $\mathrm{C}$ ).

The results described above show that GInK had only a minor effect on the expression of $g \ln A p-l a c Z Y A$ but was required to limit the expression of $g I n K p-l a c Z Y A$ and nacp-lacZYA in starved cells and was also required to lower the expression of all three fusions after starved cells were fed ammonia. Given the stability of $\beta$-galactosidase, the kinetics of deinduction primarily represent the rate of dilution of $\beta$-galactosidase that accumulated in starved cells. However, as starved strain $\mathrm{K}$ does not grow after the addition of ammonia, there is no dilution of $\beta$-galactosi-

Fig. 2. PII and GInK have distinct roles in regulating Ntr induction. The Ntr induction properties of isogenic strains carrying the glnAp-lacZYA, glnKp-lacZYA and nacp-lacZYA fusions were probed in wild-type cells, strain B and strain $\mathrm{K}$. Overnight cultures grown in $0.4 \%$ (w/v) glucose, $0.2 \%(\mathrm{w} / \mathrm{v})$ ammonium sulphate, $0.005 \%(\mathrm{w} / \mathrm{v})$ tryptophan and $50 \mu \mathrm{g} \mathrm{ml}^{-1}$ kanamycin were collected, washed once and diluted to $\mathrm{OD}_{600} \approx 0.010$ in similar media, but containing only $0.005 \%(\mathrm{w} / \mathrm{v})$ ammonium sulphate. After being held in the starved state for $\approx 18 \mathrm{~h}$, ammonia was added back to $0.2 \%(\mathrm{w} / \mathrm{v})$ as indicated by the arrow. The optical density of the cultures was followed, and samples were removed for $\beta$-galactosidase activity at the times indicated. Line graphs depict optical density of the cultures. Bar graphs represent $\beta$-galactosidase activity. Filled circles, WT strains optical density; crosses, strain B optical density; triangles, strain K optical density; hollow bars, WT strain $\beta$-galactosidase activity; solid bars, strain $B \beta$-galactosidase activity; hatched bars, strain $\mathrm{K} \beta$-galactosidase activity.

A. Strains contain the $[g \ln A p-L a c Z Y A]$ allele.

B. Strains contain the $[g \ln K p-l a c Z Y A]$ allele.

C. Strains contain the $[$ nacp-lacZYA] allele. 
dase. The fact that $\beta$-galactosidase levels continue to rise in starved cells lacking GlnK (strain K), even after the addition of ammonia, indicates that PII is unable to stop Ntr gene expression in these cells upon addition of ammonia.

\section{Phenotype of a glnK mutant}

The results described above suggested a remarkable phenomenon concerning the ability of strain $\mathrm{K}$ to grow on ammonia; this strain could grow as well as the wild type on ammonia as long as it had not been starved but, once starved, it could not grow on ammonia. This is the only significant phenotype to be associated with a glnK mutation in an otherwise wild-type background. To observe whether the results with starved liquid cultures could be discerned with solid media, we grew cells as described for Fig. 2, except that we held cells of various genotypes in the nitrogen-starved state for 12-65 h before plating the starved cells on glucose ammonia solid media containing a high concentration of $0.2 \%(\mathrm{w} / \mathrm{v})$ ammonia. The growth rates of cells starved for various lengths of time were observed by comparing colony size on solid media
(Fig. 3). Viability was also assessed by comparing the number of colony-forming units, regardless of size, with that expected for cells at that optical density (Fig. 4). The wild-type strain (YMC10), strain B (lacking PII) and strain $\mathrm{N}$ (lacking Nac) displayed no obvious defects in growth rate or viability when plated on glucose ammonia solid media, regardless of the length of time that these cells were held in the nitrogen-starved state (Figs 3 and 4 . Cells starved for $16 \mathrm{~h}$ are shown in Fig. 3). In contrast, the vast majority of strain $\mathrm{K}$ (lacking GInK) colonies were tiny pin-point colonies (Fig. 3, the pin-point colonies are barely evident in Fig. 3, but were readily apparent by close inspection of the plates). As strain $\mathrm{K}$ (which has not been starved) grows as well as the wild type on glucoseammonia media, the debilitating memory of starvation in this strain must be quite strong. We explored this 'starvation effect' further by picking several of the tiny pinpoint colonies from starved strain $\mathrm{K}$ onto fresh glucose ammonia plates. Approximately $70-90 \%$ of the resulting colonies again grew very slowly, whereas the remainder somehow escaped the roadblock and grew as well as wild type. This showed that, although there was a strong memory of starvation, the debilitation was not irreversible, at

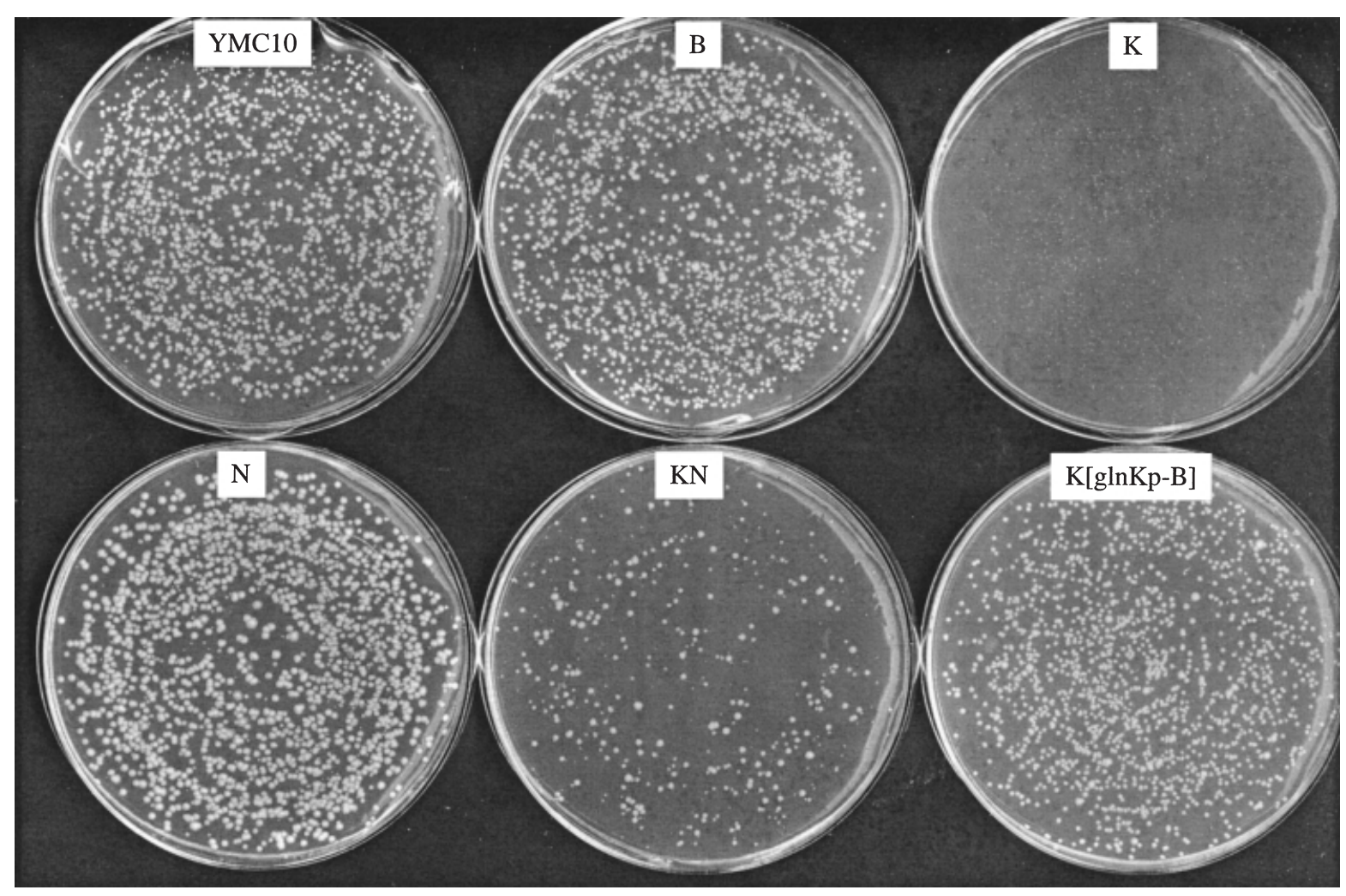

Fig. 3. GInK is required to recover from nitrogen starvation. Single colonies of strains of the indicated genotype were picked from LB plates supplemented with $0.2 \%$ (w/v) glutamine into liquid medium containing $0.4 \%$ (w/v) glucose, $0.005 \%$ (w/v) ammonium sulphate and $0.005 \%$ tryptophan and grown for $28 \mathrm{~h}$ before being plated onto solid media containing $0.4 \%(\mathrm{w} / \mathrm{v})$ glucose, $0.2 \%$ (w/v) ammonium sulphate and $0.005 \%$ (w/v) tryptophan. Plates were incubated for $33 \mathrm{~h}$ at $37^{\circ} \mathrm{C}$. 


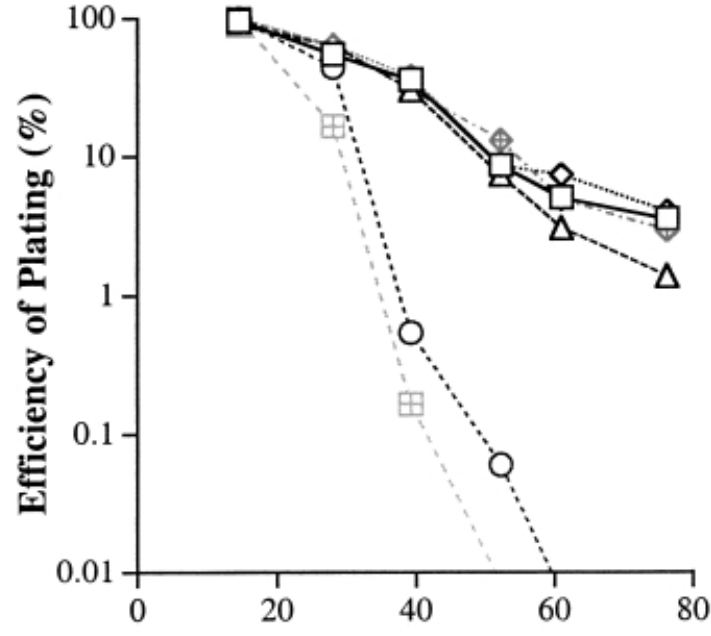

Time (Hrs)

Fig. 4. GInK required for viability during nitrogen starvation. Single colonies of strains of the indicated genotype were picked from LB plates supplemented with $0.2 \%(\mathrm{w} / \mathrm{v})$ glutamine into $0.4 \%(\mathrm{w} / \mathrm{v})$ glucose, $0.005 \%(\mathrm{w} / \mathrm{v})$ ammonium sulphate and $0.005 \%(\mathrm{w} / \mathrm{v})$ tryptophan. The optical density was monitored for $75 \mathrm{~h}$ after inoculation, and the number of viable cells per OD was calculated at the times indicated by plating a defined volume of cells on solid media containing $0.4 \%(\mathrm{w} / \mathrm{v})$ glucose, $0.2 \%(\mathrm{w} / \mathrm{v})$ ammonium sulphate and $0.005 \%$ (w/v) tryptophan at $37^{\circ} \mathrm{C}$ and counting the number of colonies (irrespective of size) that arose (see Experimental procedures). Hollow squares, WT; diamonds, B; hollow circles, K; triangles, N; filled squares, KN; filled diamonds, K[glnKp-B].

least in some cases. Interestingly, the colonies formed by strain $\mathrm{K}$ were either as large as wild type or pin-points, suggesting that the cells were able to recover either completely upon plating or not at all. Furthermore, when picked onto glucose ammonia medium supplemented with casein hydrolysate, a supplement that has been shown previously to restore good growth to strains with elevated Ntr expression (Atkinson and Ninfa, 1998; Blauwkamp and Ninfa, 2002), the pin-point colonies of starved strain $\mathrm{K}$ formed normal-sized colonies that could subsequently grow on glucose ammonia medium normally, as they could before they were starved. That is, a little good living erased the memory of hard times.

Occasionally, colonies that grew normally, relative to the wild type, appeared among the pin-point colonies upon plating starved strain $\mathrm{K}$ on glucose ammonia plates. Although none is evident on the plate shown in Fig. 3, these faster growing isolates appeared with a frequency of $\approx 0.1-0.5 \%$, relative to the pin-point colonies, depending on the experiment. The frequency of occurrence of these normal-growing colonies did not correlate with the length of starvation. We selected and purified several of the normal-growing colonies from different experiments, used them in a second ammonia exhaustion experiment and plated the starved cells onto glucose ammonia plates. These strains showed the same growth rate and viability defects as the starting strain $\mathrm{K}$ after ammonia starvation (data not shown). Thus, the very small number of cells among the starved $\mathrm{K}$ population that are able to grow on glucose ammonia seemed to be rare individuals that somehow escaped starvation.

Recently, we have shown that high levels of Nac inhibit cell growth (Blauwkamp and Ninfa, 2002). To examine whether the slow growth property of starved strain $\mathrm{K}$ resulted exclusively from runaway nac expression, we starved strain $\mathrm{KN}$ ( $g$ InK nac) in an ammonia exhaustion experiment. When this strain was starved and subsequently plated onto glucose ammonia, fewer colonies were formed than by the wild type, but the colonies that were formed were considerably larger than the pin-point colonies obtained with strain $\mathrm{K}$ and were similar in size to wild-type colonies (Fig. 3). Thus, the absence of Nac suppressed the poor growth of strain $\mathrm{K}$, but did not suppress the viability defect, suggesting that Ntr genes other than nac are also involved in the GInK phenotypes (Fig. 4).

Previous results have shown that PII expressed from the glnK promoter was able to substitute for GlnK in strains that grow poorly in the absence of GInK because of elevated Ntr levels (M. R. Atkinson et al., 2002b). Western blotting experiments have shown that the amount of PII produced from the glnK promoter under nitrogenlimiting conditions by this construct was very similar to the amount of GlnK produced by the wild-type glnK gene under identical conditions (M. R. Atkinson et al., 2002b). To dissect structural differences between PII and GInK from differences in gene expression patterns, the growth rate and viability of strain $\mathrm{K}$ [glnKp-B] was examined in an ammonia exhaustion experiment (Fig. 3). This strain lacks GlnK and has both the normal chromosomal copy of $g / n B$ and a second copy of $g \ln B$ expressed from the $g / n K$ promoter within the landing pad in the $\operatorname{trp}$ operon (M. R. Atkinson et al., 2002b). Strain K[glnKp-B] grew as fast as the wild-type strain on glucose ammonia solid media and did not show any cell viability or growth rate defects after starvation (Figs 3 and 4). This suggests that the difference between PII and GInK in starvation survival, like all other functional differences reported in $E$. coli to date (M. R. Atkinson et al., 2002b), is a result of differences in expression pattern and not structural differences between the PII and GInK proteins.

To test whether the phenotypes associated with glnK were specific to nitrogen starvation, cells were examined in glucose exhaustion experiments similar to the ammonia exhaustion experiments, using $0.01 \%$ glucose as the carbon source (Experimental procedures). Strain $\mathrm{K}$ displayed no defect relative to the wild type in the ability to grow on glucose ammonia medium or viability after carbon starvation for $12-65 \mathrm{~h}$ (data not shown). Thus, the debilitating 


\section{T. A. Blauwkamp and A. J. Ninfa}

memory of starvation of strain $\mathrm{K}$ was caused specifically by nitrogen starvation.

\section{Onset of the debilitating memory of starvation in cells lacking GlnK}

Previous experiments by M. R. Atkinson showed that, when strain $\mathrm{K}$ was starved for only short periods of time, relative to those used in our studies, it did not display an obvious defect in recovery from starvation (M. R. Atkinson, unpublished data). We re-examined this, as the results shown in Fig. $2 \mathrm{C}$ indicated that runaway expression of nac-lacZYA in the strain $\mathrm{K}$ required about $6-7 \mathrm{~h}$ of starvation before the level of reporter activity was clearly exceeding the maximum level detected in wild-type starved cells. Furthermore, in additional experiments with gene fusions, we observed in a small number of experiments that several hours of starvation seemed to be required to obtain runaway expression of $g / n K$ and nac fusions (data not shown). Thus, we examined the effect of starvation for increasing times on the subsequent growth of cells after feeding starved cells ammonia. We observed that, for the wild type, there was no significant memory of starvation for up to $20 \mathrm{~h}$ of starvation, the longest period examined in the experiment. In contrast, cells lacking GInK began showing significant signs of the debilitating memory of starvation after $10 \mathrm{~h}$ of starvation. This was evident in two ways: the cells showed a clearly discernible decrease in culture turbidity after the addition of ammonia, and a slower apparent growth rate when the turbidity increased above that at which they were fed ammonia (data not shown). Both these became progressively worse as the length of starvation increased, such that, after $20 \mathrm{~h}$ starvation, the period of decreasing turbidity lasted for $75 \mathrm{~min}$, and the subsequent apparent growth rate was about one-third that obtained with unstarved cells (data not shown).

\section{The growth rate defect of starved strain $K$ results from Nac-mediated inhibition of serine biosynthesis}

We have shown elsewhere that the growth defect of strains lacking PII and GInK results from overexpression of Nac, which inhibits serine biosynthesis by mediating the repression of serA (Blauwkamp and Ninfa, 2002). Glycine, which is converted to serine by the reversible action of serine hydroxymethyl transferase (SHMT), has been shown to rescue this growth phenotype in combination with very low levels $(0.005 \% \mathrm{w} / \mathrm{v})$ of isoleucine, leucine and valine (Blauwkamp and Ninfa, 2002). Isoleucine was included at very low concentrations to offset the serine toxicity that occurs at high intracellular concentrations of serine, presumably the result of glycine conversion to serine by SHMT (Stauffer, 1996). We examined whether nac deletion or the addition of glycine to the medium would permit starved strain $\mathrm{K}$ to grow on ammonia, and whether these treatments brought about a reduction in the expression of Ntr genes in starved strain K. As shown in Fig. 5A, starved strain KN displayed a short lag after dilution but soon thereafter grew at the wild-type rate. In contrast, starved strain $\mathrm{K}$ displayed an extended lag, after which the apparent growth rate was less than the wild type. Likewise, dilution of strain $\mathrm{K}$ into media supplemented with glycine also restored wild-type growth rates to strain $\mathrm{K}$ after nitrogen starvation as shown (Fig. 5B). These results suggest that the growth rate defect of starved strain $\mathrm{K}$ results from $\mathrm{Nac}-$ mediated repression of serA.

The effects of glnK mutation, nac mutation or the addition of glycine on Ntr induction

$\beta$-Galactosidase activity was measured before, during and after nitrogen starvation (Fig. $5 \mathrm{C}$ and D). As shown on the left of Fig. $5 \mathrm{C}$ and $\mathrm{D}$, neither wild-type, $\mathrm{K}$ nor $\mathrm{KN}$ cells begin producing $\beta$-galactosidase from the $g$ InK promoter until the cells depleted the ammonia supply, an event that occurred soon after the cultures reach OD 0.2 for all strains. After this point, all the strains grew slowly and rapidly accumulated $\beta$-galactosidase; wild-type cells accumulated $\beta$-galactosidase to $\approx 300$ units $\mathrm{ml}^{-1}$, whereas $\mathrm{K}$ and $\mathrm{KN}$ strains continued to accumulate $\beta$-galactosidase to $\approx 1100$ units $\mathrm{ml}^{-1}$. As shown, strains $\mathrm{K}$ and $\mathrm{KN}$ continued to express glnKp-lacZYA far beyond the OD at which wild-type cells had ceased expressing this fusion (Fig. 5C and $D$, left). When diluted into fresh media containing $0.005 \%$ ammonium sulphate as the nitrogen source, wildtype cells again failed to accumulate significant levels of $\beta$-galactosidase until the ammonia was depleted from the subculture (Fig. $5 \mathrm{C}$ and D, right). Strains $\mathrm{K}$ and $\mathrm{KN}$ on the other hand showed a significant and constant rate of $\beta$-galactosidase accumulation until the ammonia was depleted from the subculture, after which the rate of accumulation with respect to culture density increased concurrent with the decrease in growth rate (Fig. 5C, right). Similar results were obtained when glycine was used to rescue the growth of strain $\mathrm{K}$ after nitrogen starvation; strain $\mathrm{K}$ subcultured into media supplemented with glycine or similar unsupplemented media showed similar constant rates of $\beta$-galactosidase accumulation until the ammonia was depleted (Fig. 5D, right). These results show that nac deletion and the addition of glycine to the growth media do not rescue the growth of starved strain $\mathrm{K}$ by lowering Ntr induction levels.

This conclusion is strengthened upon consideration of the rate of $\beta$-galactosidase accumulation in the cultures shown in Fig. 5. Effects of GInK, Nac and glycine on glnK expression are shown in Table 2, where the rate of $\beta$-galactosidase accumulation per cell, i.e. the glnK pro- 

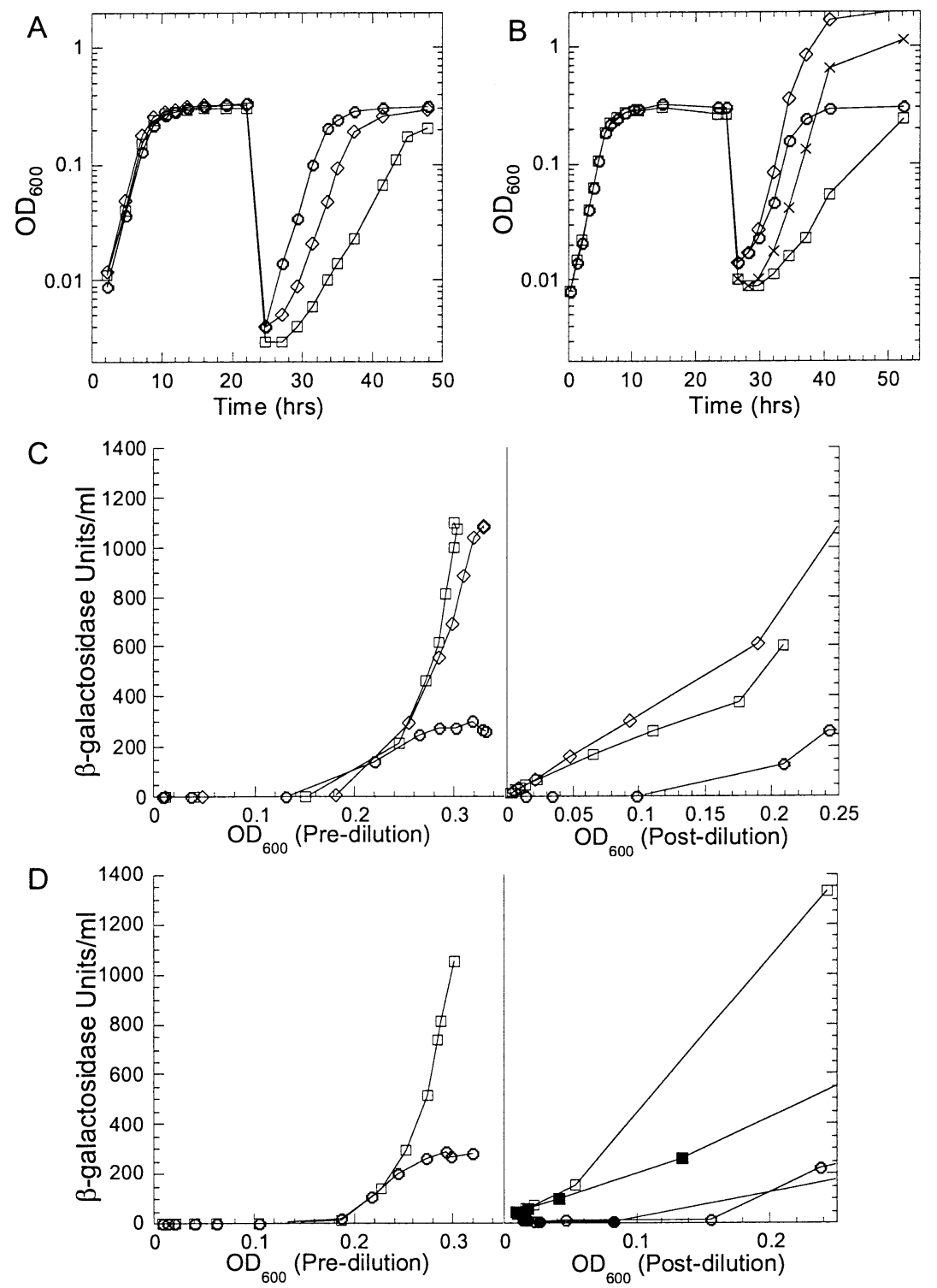

Fig. 5. Factors affecting the growth rate defect of starved strain $\mathrm{K}$.

A. Overnight cultures of the indicated strains grown in media containing $0.4 \%(\mathrm{w} / \mathrm{v})$ glucose, $0.2 \%(\mathrm{w} / \mathrm{v})$ ammonium sulphate and $0.005 \%$ tryptophan were washed in media similar to the above except containing $0.005 \%(\mathrm{w} / \mathrm{v})$ ammonium sulphate and diluted to $\mathrm{OD}_{600} \approx 0.005$ in the same media. Cells were subcultured into identical media after $\approx 14 \mathrm{~h}$ of starvation. Aliquots of the culture were removed at the indicated times and assayed for $\beta$-galactosidase activity. Circles, WT; squares, K; diamonds, KN. $B$. Cells of the indicated genotype were grown as described above except that cells starved for $\approx 15 \mathrm{~h}$ were diluted into media containing and not containing $0.1 \%(\mathrm{w} / \mathrm{v})$ glycine and $0.005 \%$ $(w / v)$ each of isoleucine, leucine and valine. Circles, WT without glycine; squares, $\mathrm{K}$ without glycine; diamonds, WT plus gly; crosses, $\mathrm{K}$ plus glycine.

C. The $\beta$-galactosidase activity $\mathrm{ml}^{-1}$ of cultures shown in $(A)$ is shown as a function of culture density and growth phase. Circles, WT; squares, $\mathrm{K}$; diamonds, $\mathrm{KN}$.

$\mathrm{D}$. The $\beta$-galactosidase activity $\mathrm{ml}^{-1}$ of cultures shown in (B) is shown as a function of culture density and growth phase. Circles, WT;

squares, K; filled circles, WT plus glycine; filled squares, $\mathrm{K}$ plus glycine. moter firing rate, is described at each of the three main stages of growth: initial log-phase growth on $0.005 \%$ ammonium sulphate, nitrogen starvation during stationary phase, and nitrogen-rich log-phase growth after subculture. The main difference in strains lacking GInK is the post-starvation nitrogen-rich promoter firing rate, which is similar to the maximum nitrogen-starved firing rate of wildtype cells. glnK mutation has only a moderate $(<1.5$-fold $)$ effect on the ginK promoter firing rate during starvation. It is also clear that neither deletion of Nac nor addition of

Table 2. Effects of GlnK, Nac and glycine on glnK promoter firing rate.

gInK promoter firing rate

$\left(\Delta \beta \text {-galactosidase units } \mathrm{h}^{-1} \approx 10^{-9} \text { cells }\right)^{\text {a }}$

\begin{tabular}{lllll}
\cline { 2 - 5 } Strain & N-rich (prestarvation) & Max. N-poor (during starvation) & N-rich (post-starvation) & N-rich \pm Gly (post-starvation) \\
\hline WT & $<5$ & 465 & $<5$ & $<5$ \\
K & $<5$ & 668 & 545 & 714 \\
KN & $<5$ & 661 & 1330 & ND
\end{tabular}

a. Values shown were calculated using the data shown in Fig. 5.

C 2002 Blackwell Publishing Ltd, Molecular Microbiology, 46, 203-214 


\section{T. A. Blauwkamp and A. J. Ninfa}

glycine to the growth media restore growth to strain $\mathrm{K}$ by lowering Ntr induction. Indeed, deletion of Nac even results in more than twice the glnK promoter firing rate of strain $\mathrm{K}$ after starvation; however, the significance of this twofold increase is unclear relative to the 100 -fold change that strain $\mathrm{K}$ shows relative to wild type.

\section{Discussion}

Our data suggest that E. coli uses PII and GInK to control the levels of NRI P during different stages of the bacterial response to nitrogen limitation. Specifically, PII was necessary to control the NRI P level at the low end of its physiological range, such as during exponential growth on ammonia, whereas GInK was necessary to control the $\mathrm{NRI} \sim \mathrm{P}$ at the high end of its physiological range, such as during nitrogen starvation. The physiological role of GlnK was highlighted in the decreased viability during nitrogen starvation and the inability to resume rapid growth in ammonia after nitrogen starvation exhibited by cells lacking GInK. Apparently, the fixed amount of PII is insufficient to control NRI P levels during nitrogen starvation, as expression of PII from the glnK promoter was able to prevent the viability and growth rate defects of strains lacking GlnK.

Interestingly, in cells lacking GInK, the $g \ln A$ promoter did not exhibit the runaway expression exhibited by $g / n K$ and nac promoters upon ammonia run-out, suggesting silencing mechanisms at this promoter. Silencing of glutamine synthetase expression upon elevated Ntr induction has been observed previously. For example, overexpression of $\mathrm{NRI}$ from the lac promoter on a multicopy plasmid limits the expression of $g \ln A$, even under nitrogen-limiting conditions (Shiau et al., 1992). Our experiments in which the $g \ln A$ promoter was compared with the $g / n K$ and nac promoters show strong evidence for silencing of the $g \ln A$ promoter under physiological conditions. As the glnAp-lacZYA fusion did not show this runaway expression, the expression profiles of $g \operatorname{lnK}$ and nac do not reflect unchecked amplification of the positive autoregulatory loop producing NRI. Indeed, examination of NRI P levels by Western blot has shown that NRI P levels only increase five- to 10-fold when grown on glutamine as the sole nitrogen source (Reitzer and Magasanik, 1985) or when cells exhaust a limiting supply of ammonia (M. R. Atkinson et al., 2002a). Rather, our results suggest that the runaway expression of $g \operatorname{lnK}$ and nac results from the unregulated kinase activity of NRII and the absence of NRII phosphatase activity when NRII is at the maximum concentration obtainable (because of silencing of $g \ln A p$ expression by high NRI P). It is apparent then that, in wild-type cells, GlnK acted as a negative regulator of gene expression in cells that have stopped growing because they were starved for ammonia. We interpret this as indicating that, even upon ammonia exhaustion, the presence of GlnK activates the phosphatase activity of NRII such that the level of NRI P is well below its maximum and full induction of the Ntr system is not achieved. As UTase/UR is thought to uridylylate PII and GInK under conditions of nitrogen limitation (Atkinson and Ninfa, 1999), the inactivation of GlnK by uridylylation or by allosteric regulation by 2-ketoglutarate must be incomplete under these conditions. Consistent with this interpretation, previous immunoblotting experiments have shown that, on the moderately nitrogenlimiting glucose glutamine medium, both unuridylylated and uridylylated GInK subunits are present in the cell (van Heeswijk et al., 1996). Thus, we hypothesize that incomplete covalent modification of GInK leads to regulation of the NRI P concentration after ammonia run-out. As the incomplete inactivation of GInK prevents the viability and growth rate defects associated with cells lacking GInK, this may well be the reason why E. coli maintains an inducible PII-like protein. Thus, the Ntr system contains two "capping' mechanisms: the silencing of $g \ln A L G$, which limits the total amount of $\mathrm{NRI}$ in the cell, and the inability to inactivate GInK completely, which limits the ratio of NRI P to $\mathrm{NRI}$ at high total NRI concentrations. Preventing inappropriately high Ntr gene expression appears to be an important component of Ntr regulation, which is evident from the phenotypes associated with loss of this regulation.

Based on this work, three distinct physiological states of nitrogen status may be described. Nitrogen-excess conditions (LB or casein hydrolysate) permit rapid growth, and the $g \ln A$ gene encoding glutamine synthetase is not highly expressed. Nitrogen-sufficient conditions, such as growth on ammonia as the nitrogen source, are characterized by partial induction of $g \ln A$, without induction of nac or glnK. Nitrogen limitation, such as occurs when wildtype cells use an alternative nitrogen source or deplete the available ammonia and stop growing, is characterized by high, but regulated, expression of glnK and nac. A hypothetical fourth state is proposed to occur after ammonia exhaustion and some other stimulus, where GInK is inactivated (or absent) and glnK and nac (and presumably other Ntr-regulated genes) are expressed at full potential. Although not observed in these experiments, we speculate that environmental conditions may exist that completely inactivate GInK in wild-type cells and result in expression of Ntr genes at the levels observed in starved cells lacking GlnK. For example, allosteric regulation by a small molecule effector, complete uridylylation of GInK by the UTase/UR or an unknown mechanism or combination of mechanisms may prevent the regulation of NRII by GInK. In the complete absence of NRII phosphatase activity, the level of NRI P would rise to its maximum level, 
resulting in a high level of nac and other Ntr gene expression. If such conditions exist, the elevated Ntr induction observed in strain $\mathrm{K}$ would presumably have unidentified benefits under those conditions. Our experiments show that simple starvation for ammonia in the presence of glucose is not sufficient to elicit this hypothetical fourth state in wild-type cells.

Recently, GInK was found to be specifically required to relieve NifL inhibition of NifA activity in Klebsiella pneumoniae, suggesting that one or more of the few structural differences between PII and GInK may be responsible for imparting unique biochemical interactions to GlnK. Indeed, changing residues 43 and 54 of PII to the analogous GInK residues allowed PII to relieve NifL inhibition of NifA when it was present on multicopy plasmids (Arcondeguy et al., 2000). However, wild-type PII on a multicopy plasmid has also been shown to relieve NifL inhibition of NifA, although not to the extent that PII could with the changes at residue 43 and 54 (Jack et al., 1999). The sequence and expression characteristics of $K$. pneumoniae PII and GInK are identical to the E. coli genes, suggesting that the specificity of GInK regulation of NifL inhibition of NifA may result simply from the greater amount of GInK present. Indeed, the unique functions of PII or GInK in E. coli have recently been shown to be caused by the expression characteristics, not structural differences, as shown by expressing PII or GInK from the various Ntr regulated or constitutive promoters (M. R. Atkinson et al., 2002b). Here, we have seen that expression of PII from the glnK promoter (in place of GlnK) prevented the onset of the debilitating memory of starvation characteristic of cells that lack GInK. Thus, the reason that PII expressed from its natural promoter is unable to control GInK or Nac expression in cells lacking GInK is also probably due to the fixed level of PII when expressed from its wild-type promoter. The ability of PII, when expressed from the glnK promoter, to prevent the onset of the debilitating memory of starvation indicates that no special feature of GInK, not shared by PII, is responsible for these phenotypes.

\section{Experimental procedures}

\section{Bacterial strains and genetic techniques}

Bacterial strains and plasmids used in this study are shown in Table 1. Minimal media was W-salts (Pahel et al., 1978) supplemented with $0.005 \%$ thymine and the following as indicated: $0.4 \%$ glucose $(\mathrm{G}), 0.2 \%\left(\mathrm{NH}_{4}\right)_{2} \mathrm{SO}_{4}(\mathrm{~N}), 0.005 \%$ $\left(\mathrm{NH}_{4}\right)_{2} \mathrm{SO}_{4}, 0.005 \%$ tryptophan (t) and $0.1 \%$ casamino acids (CAA) (Difco) unless otherwise noted in the text. Ampicillin $\left(100 \mu \mathrm{g} \mathrm{ml}^{-1}\right)$, kanamycin $\left(50 \mu \mathrm{g} \mathrm{ml}^{-1}\right)$, tetracycline $\left(20 \mu \mathrm{g} \mathrm{ml}^{-1}\right)$, gentimicin $\left(10 \mu \mathrm{g} \mathrm{ml}^{-1}\right.$ on W-salts, $50 \mu \mathrm{g} \mathrm{ml}^{-1}$ on LB), spectinomycin $\left(50 \mu \mathrm{g} \mathrm{ml}^{-1}\right)$ and streptomycin $\left(25 \mathrm{\mu g} \mathrm{ml}^{-1}\right.$ ) were used when necessary. Media used in liquid cultures were filter sterilized before use, and media used in plates were autoclaved and combined with $1.5 \%(\mathrm{w} / \mathrm{v})$ Bacto agar (Difco). Generalized transduction was performed as described previously using P1vir (Silhavy et al., 1984). Transformation with plasmid DNA was performed as described previously (Maniatis et al., 1982). Transformation with linear DNA to obtain recombination onto the chromosome was performed by electroporation of the recipient strain with $\approx 0.5 \mu \mathrm{g}$ of gel-purified linear DNA in water using a Bio-Rad Gene Pulser apparatus. Transformants were selected on rich LB+glutamine medium and supplemented with the appropriate drug. Generalized P1vir transduction was used to move the antibiotic marker and linked mutations to various strains.

\section{Measurement of glnAp2, glnK and nac promoter induction} upon ammonia exhaustion

Overnight cultures of the indicated strains grown in minimal media containing $0.4 \%(\mathrm{w} / \mathrm{v})$ glucose, $0.2 \%(\mathrm{w} / \mathrm{v})$ ammonium sulphate, $0.005 \%$ tryptophan were washed twice and diluted 1:500 into media containing $0.4 \%(\mathrm{w} / \mathrm{v})$ glucose, $0.005 \%(\mathrm{w} / \mathrm{v})$ ammonium sulphate and $0.005 \%(\mathrm{w} / \mathrm{v})$ tryptophan. Optical density at $600 \mathrm{~nm}$ was monitored in a Beckman DU65 spectrophotometer. $\beta$-Galactosidase activity was measured by the Miller assay and expressed as Miller units, using SDS and chloroform to disrupt the cells, as described previously (Miller, 1992). Where indicated in the text, ammonium sulphate was added to $0.2 \%$ by $1: 100$ dilution of $20 \%(\mathrm{w} / \mathrm{v})$ ammonium sulphate.

\section{Measurement of cell growth and viability on solid media}

Minimal media cultures $(25 \mathrm{ml})$ containing $0.4 \%(\mathrm{w} / \mathrm{v})$ glucose, $0.005 \%(\mathrm{w} / \mathrm{v})$ ammonium sulphate and $0.005 \%(\mathrm{w} / \mathrm{v})$ tryptophan were inoculated from single colonies on LB media supplemented with $0.2 \%$ glutamine and growth at $37^{\circ} \mathrm{C}$ while shaking at 300 r.p.m. Optical density was determined in a Beckman DU65 spectrophotometer, and cell growth rate, efficiency of plating and viability were determined by removing a sample of known optical density, diluting the sample $1: 10000$, plating $10 \mu \mathrm{l}$ on solid media containing $0.4 \%(\mathrm{w} / \mathrm{v})$ glucose, $0.2 \%(\mathrm{w} / \mathrm{v})$ ammonium sulphate, $0.005 \%(\mathrm{w} / \mathrm{v})$ tryptophan and $0.1 \%(\mathrm{w} / \mathrm{v})$ casein hydrolysate, where indicated, and counting colonies. Efficiency of plating (EOP) was determined by dividing the total number of colonies, irrespective of size, by the number of colonies expected based on $10^{9}$ cells $\mathrm{ml}^{-1}$ at an $\mathrm{OD}_{600}$ of 1.0 . Strains that grew poorly (i.e. K) were allowed to grow longer, such that the number of slower growing colonies was scored accurately.

\section{Measurement of GInK, Nac and glycine effects on cell growth and glnK promoter induction}

Overnight cultures of the indicated strains grown in minimal media containing $0.4 \%(\mathrm{w} / \mathrm{v})$ glucose, $0.2 \%(\mathrm{w} / \mathrm{v})$ ammonium sulphate and $0.005 \%$ tryptophan were washed twice and diluted 1:500 into media containing $0.4 \%(\mathrm{w} / \mathrm{v})$ glucose, $0.005 \%(\mathrm{w} / \mathrm{v})$ ammonium sulphate and $0.005 \%(\mathrm{w} / \mathrm{v})$ tryptophan. Optical density at $600 \mathrm{~nm}$ was monitored in a Beckman DU65 spectrophotometer. $\beta$-Galactosidase activity 
was measured by the Miller assay, using SDS and chloroform to disrupt the cells, as described previously (Miller, 1992). One unit of $\beta$-galactosidase hydrolyses $1 \mu \mathrm{mol}$ of ONPG to o-nitrophenol and galactose in $1 \mathrm{~min}$ at $28^{\circ} \mathrm{C}, \mathrm{pH} 7.5$. Where indicated, cells were subcultured into media identical to the original growth media with or without supplementation with $0.1 \%(\mathrm{w} / \mathrm{v})$ glycine and $0.005 \%(\mathrm{w} / \mathrm{v})$ each isoleucine, leucine and valine. The glnK promoter firing rate was determined by dividing the change in $\beta$-galactosidase units $\mathrm{ml}^{-1}$ by the time elapsed between measurements and by the change in optical density of the cultures at $600 \mathrm{~nm}$ between measurements, assuming $10^{9}$ cells $\mathrm{ml}^{-1}$ when $\mathrm{OD}_{600}=1$.

\section{Acknowledgements}

We thank Boris Magasanik and Bob Bender for helpful comments and discussions. Supported by grant GM57393 from the NIH-NIGMS.

\section{References}

Arcondeguy, T., van Heeswijk, W.C., and Merrick, M. (1999) Studies on the roles of GlnK and GlnB in regulating Klebsiella pneumoniae NifL-dependent nitrogen control. FEMS Microbiol Lett 180: 263-270.

Arcondeguy, T., Lawson, D., and Merrick, M. (2000) Two residues in the T-loop of GInK determine NifL-dependent nitrogen control of nif gene expression. J Biol Chem 275: 38452-38456.

Atkinson, M.R., and Ninfa, A.J. (1993) Mutational analysis of the bacterial signal-transducing protein kinase/phosphatase nitrogen regulator II (NRII or NtrB). J Bacteriol 175: 7016-7023.

Atkinson, M.R., and Ninfa, A.J. (1998) Role of the GInK signal transduction protein in the regulation of nitrogen assimilation in Escherichia coli. Mol Microbiol 29: 431-447.

Atkinson, M.R., and Ninfa, A.J. (1999) Characterization of the GInK protein of Escherichia coli. Mol Microbiol 32: 301313.

Atkinson, M.R., Blauwkamp, T.A., Bondarenko, V.A., Studitsky, V.M., and Ninfa, A.J. (2002a) Activation of the $g \ln A, g \ln K$, and nac promoters as Escherichia coli makes the transition from growth on ammonia to nitrogen starvation. $J$ Bacteriol (in press).

Atkinson, M.R., Blauwkamp, T.A., and Ninfa, A.J. (2002b) Context-dependent functions of the PII and GInK signaltransduction proteins in Escherichia coli. $J$ Bacteriol (in press).

Backman, K., Chen, Y.-M., and Magasanik, B. (1981) Physical and genetic characterization of the $g \ln A-g \ln G$ region of the Escherichia coli chromosome. Proc Natl Acad Sci USA 78: 3743-3747.

Blauwkamp, T.A., and Ninfa, A.J. (2002) Nac-mediated repression of the serA promoter in Escherichia coli. Mol Microbiol 45: 351-363.
Bueno, R., Pahel, G., and Magasanik, B. (1985) Role of $g \ln B$ and $g \ln D$ gene products in regulation of the $g \ln A L G$ operon of Escherichia coli. J Bacteriol 164: 816-822.

Feng, J., Goss, T.J., Bender, R.A., and Ninfa, A.J. (1995) Activation of transcription initiation from the nac promoter of Klebsiella aerogenes. J Bacteriol 19: 5523-5534.

van Heeswijk, W.C., Hoving, S., Molenaar, D., Stegeman, B., Kahn, D., and Westerhoff, H.V. (1996) An alternative PII protein in the regulation of glutamine synthetase in Escherichia coli. Mol Microbiol 21: 133-146.

Jack, R., De Zamaroczy, M., and Merrick, M. (1999) The signal transduction protein GlnK is required for NifLdependent nitrogen control of nif gene expression in Klebsiella pneumoniae. J Bacteriol 181: 1156-1162.

Kustu, S., Santero, E., Keener, J., Popham, D., and Weiss, D. (1989) Expression of a sigma 54 (ntrA)-dependent genes is probably united by a common mechanism. Microbiol Rev 53: 367-376.

Maniatis, T., Fritsch, E.F., and Sambrook, J. (1982) Molecular Cloning, A Laboratory Manual. Cold Spring Harbor, NY: Cold Spring Harbor Laboratory Press, pp. 68 and 250.

Merrick, M.J., and Edwards, R.A. (1995) Nitrogen control in bacteria. Microbiol Rev 59: 604-622.

Miller, J.H. (1992) A Short Course in Bacterial Genetics. A Laboratory Manual and Handbook for Escherichia coli and Related Bacteria. Cold Spring Harbor, NY: Cold Spring Harbor Laboratory Press, pp. 72-74.

Ninfa, A.J., Jiang, P., Atkinson, M.R., and Peliska, J.A. (2000) Integration of antagonistic signals in the regulation of nitrogen assimilation in Escherichia coli. Curr Topics Cell Regul 36: 31-75.

Pahel, G., Zelentz, A.D., and Tyler, B.M. (1978) gltB gene and regulation of nitrogen metabolism by glutamine synthetase in Escherichia coli. J Bacteriol 133: 139148.

Pahel, G., Rothstein, D.M., and Magasanik, B. (1982) Complex glnA-glnL-glnG operon of Escherichia coli. $J$ Bacteriol 150: 202-213.

Reitzer, L.J., and Magasanik, B. (1985) Expression of $g \ln A$ in Escherichia coli is regulated at tandem promoters. Proc Natl Acad Sci USA 82: 1979-1983.

Shiau, S.P., Schneider, B.L., Gu, W., and Reitzer, L.J. (1992) Role of nitrogen regulator I (NtrC), the transcriptional activator of $g \ln A$. enteric bacteria, in reducing expression of glnA during nitrogen-limited growth. J Bacteriol 174: 179185.

Silhavy, T.J., Berman, M.L., and Enquist, L.W. (1984) Experiments with Gene Fusions. Cold Spring Harbor, NY: Cold Spring Harbor Laboratory Press, pp. 107-112.

Simons, R.W., Houman, F., and Kleckner, N. (1987) Improved single copy and multicopy lac-based cloning vectors for protein and operon fusions. Gene 53: 85-96.

Stauffer, G.V. (1996) Biosynthesis of serine, glycine, and one-carbon units. In Escherichia coli and Salmonella. Cellular and Molecular Biology, 2nd edn. Neidhardt, F.C. (ed. in chief). Washington, DC: American Society for Microbiology Press, pp. 506-513. 